\title{
Record of paraglacial environment with examples from Central Poland and its role in morphogenesis of the area
}

\author{
Zbigniew Rdzany \\ Department of Physical Geography, Faculty of Geographical Sciences, University of Łódź, e-mail: zbigniew.rdzany@uni.lodz.pl
}

\begin{abstract}
This article analyses the characteristics of paraglacial environment that are recorded in sediments and forms, within the context of the development of views on the relief of Central Poland in the area beyond the extent of the Vistulian (Weichselian) Glaciation. The original relief of the analysed area was formed during the Warta Glaciation (Wartanian, Late Saalian). Until the 1950s, the relief was considered as glacial, when the opinion that periglacial morphogenesis had great significance was prevalent. According to the hypothesis, periglacial processes dominated the original glacial relief, until denudational periglacial plains with tors were formed. However, since the 1960s, more and more data have been documented concerning good preservation of fragments of glacial landscape, particularly within the range of kame fields. In the 1990s, a concept of polygenesis of the relief was presented, stressing the importance of periglacial environment. However, it must be noted that all views on the genesis of the area that have been presented so far still have a gap in the light of contemporary interpretation of the concept of periglacial environment. There is a need to take into account the so-called paraglacial environment, which has hardly been distinguished until now in areas of Pleistocene glaciation. According to present knowledge, the relief of the Warta belt in Central Poland should be recognised as polygenic with predominant features of old glacial relief and with elements of paraglacial, periglacial and fluvio-denudational relief from moderate periods.
\end{abstract}

Key words: paraglacial environment, old glacial landscape, Central Poland

\section{Introduction}

This article presents characteristics of paraglacial environment recorded in sediments and forms of Central Poland within the context of the development of views on the genesis of the relief. The analysed region was last glaciated during the Warta Glaciation (Wartanian, Late Saalian, Middle Polish Complex) - directly before the Eemian interglacial period. The area stretches from the maximum ice-sheet extent of the Vistulian Glaciation (LGM) to the maximum advance of the Warta Glaciation in the axial part of the Pilica River basin. In the west, it reaches the plateaux in the middle Warta valley (approx. $18^{\circ} 30^{\prime} \mathrm{E}$ ), and in the east - the eastern plateaux along the Rawka valley (approx. $20^{\circ} 45^{\prime}$, Fig. 1).

Until the 1950s, relief of this area was regarded as glacial, and its main glacial forms included "glacial uplands", eskers, terminal moraines and "diluvial gravel forms" (Lencewicz 1927). Formulating the concept of periglacial morphogenesis by Jan Dylik $(1952,1953)$ started the period of views that cold climate processes were of great significance. The processes were believed to have dominated the original glacial relief, leaving mainly areas of periglacial plains with periglacial tors (Fig. 2). Since the 1960 s, more and more data were gathered on good preservation of vast fragments of glacial landscape, particularly within the range of kame fields (Klajnert 1966, Klatkowa 1972). In the 1990s, a concept of polygenesis of the relief was presented, which quite strongly sustained the view that periglacial morphogenesis was significant in many locations, including river valleys (Turkowska 2006).

It must be noted that the concepts so far still have a gap in the light of contemporary interpretation of the idea of periglacial environment (Brown and Kupsch 1995, French 2007), as there are difficulties with classifying some sediment structures or relief forms. In particular, there is a need for the so-called paraglacial environment, so far hardly distinguished in areas of Pleistocene glaciation, to be taken into account.

The aim of this article is to present the importance of paraglacial processes and forms in the relief and sediments of the analysed area in relation to the remaining morphogenetic environments, as well as to update the views on the importance of individual morphogenetic environments in the evolution of relief and in the image of polygenetic - old glacial - relief. 


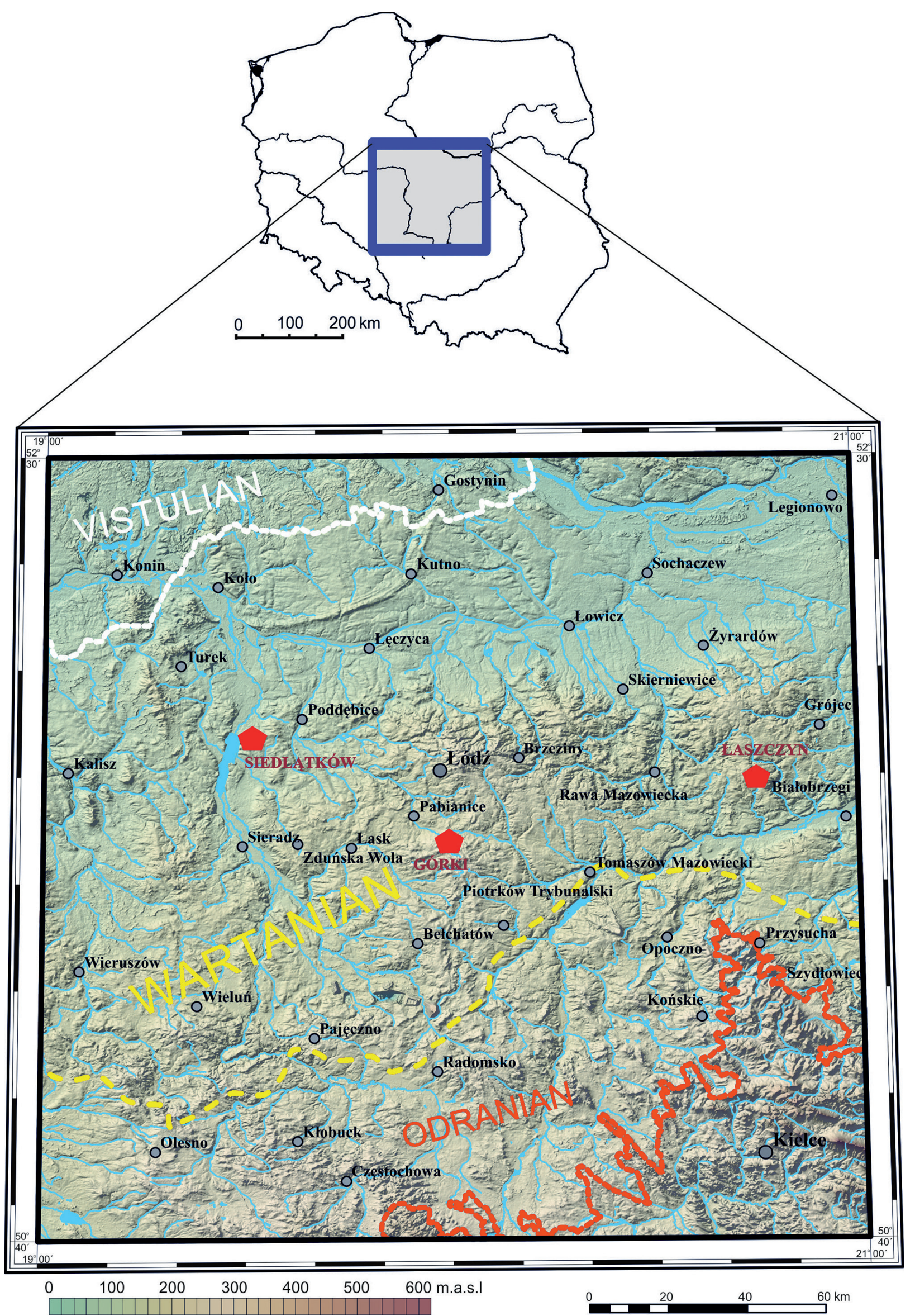

Fig. 1. The analysed area with reference to extent lines of Odranian, Wartanian and Vistulian (Weichselian) glaciations Polygons represent studied sites. 


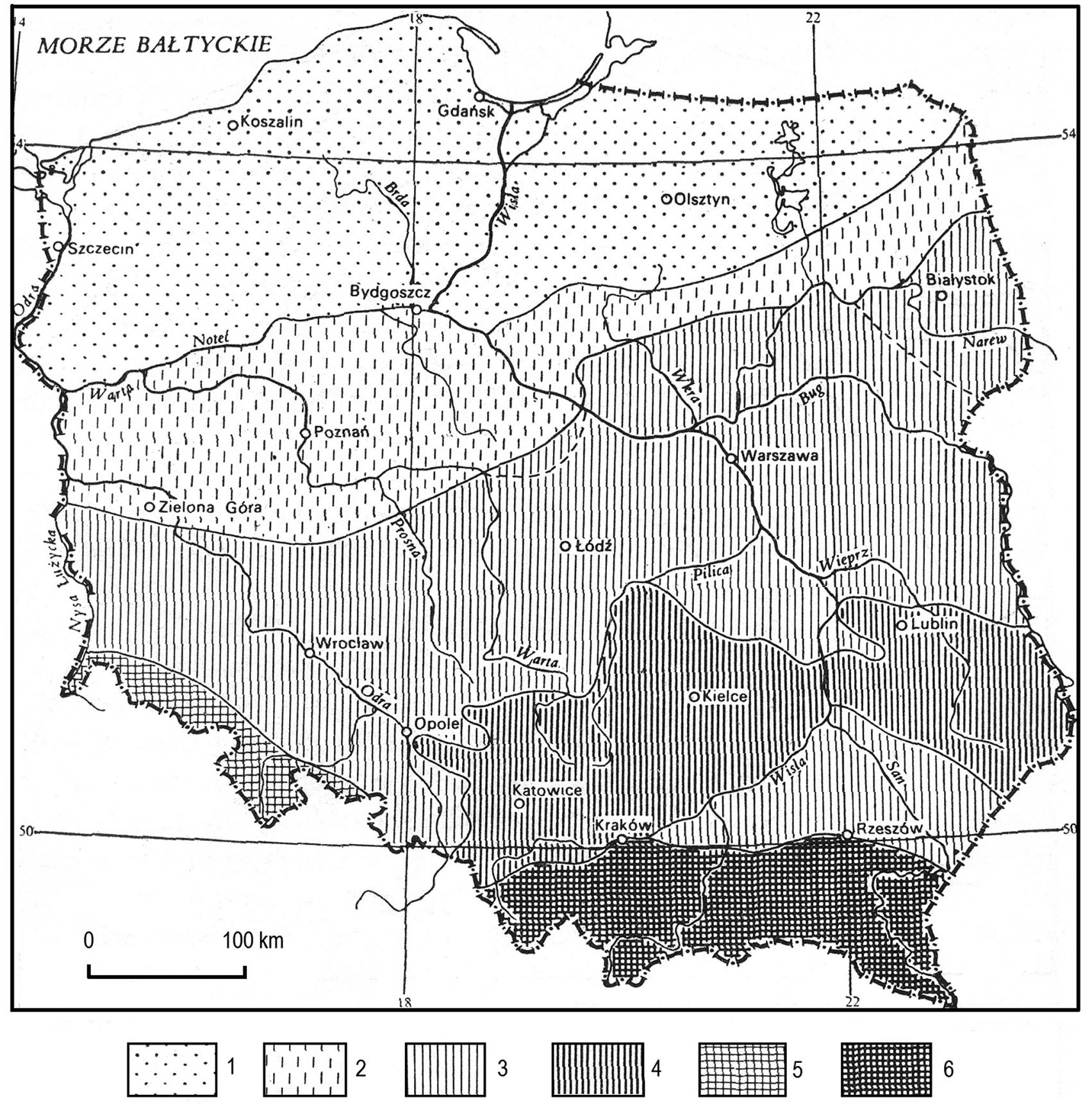

Fig. 2. Periglacial zone of the last glaciation according to J. Dylik (drawing based on Jahn 1970)

1 - area of glacial morphogenesis with traces of periglacial environment, 2 - periglacially transformed glacial area, 3 - periglacial area on glacial accumulation landforms, 4 - area of periglacial morphogenesis with relief of pre-Pleistocene denudation, 5 - area of periglacial modelling upon old fold structures, 6 - area of periglacial modelling upon young fold structures.

\section{Methodology}

Field studies were conducted in selected artificial outcrops (excavations) in different parts of the Łódź region. Fragmentary geomorphologic charting and analyses of lithological composition on walls of the outcrops were performed. Several characteristic examples of sediments and structures were chosen for the paper. The analysed lithofacies were described in accordance with the methodology introduced by Miall $(1977,1978)$ and Eyles et al. (1983), as modified by Zieliński and Pisarska-Jamroży
(2012) to adapt it to the specificity of quaternary sediments in lowland Poland.

\section{Morphogenetic environments of the Warta Glaciation area in Central Poland}

Wartanian relief in Poland forms a belt of land ranging from several to over 200 kilometres of width, accompanying the young glacial zone from the south. In the Łódź 
Region, the zone is about $110-150 \mathrm{~km}$ wide (Rdzany 2009, Fig. 1). During the development of views on its postglacial evolution, tendencies have shown to assign different morphogenetic environments the key role in shaping the current form of the landscape.

In the middle of the previous century, the relief of this area was widely regarded as glacial. The main postglacial landforms included "glacial uplands", terminal moraines, eskers and "diluvial gravel forms" (Lencewicz 1927). Formulating the concept of periglacial morphogenesis by Jan Dylik $(1952,1953)$ started the period of views which assigned the key role in morphogenesis to periglacial processes of the last cold stage. Periglacial processes, in particular slope processes, were thought to dominate the original glacial relief, of which mainly areas of periglacial pediments with periglacial tors were left. A hypothesis also appeared that cryoplanation plains exist near Łódź (Dylik 1954).

In the next dozen or so years, more and more data were published concerning good preservation of vast fragments of glacial landscape, especially within the range of moraine plateaux and extensive kame sets (Klajnert 1966, 1978, 1984, Klatkowa 1972, Krzemiński 1974, Rdzany 1997 and other authors). Studies of the region showed the important, though diversified, role of fluvial processes of moderate periods: the Eemian interglacial period and Holocene, restricted to river valleys (Krzemiński 1974, Turkowska 1988, 1996, Petera 2002, Twardy 2008).

The 1990s revealed popularisation of the concept of relief polygenesis, including somewhat tempered (in comparison with Jan Dylik's concept) opinion on the role of Vistulian periglacial processes in the morphogenesis of the area. Examples of relatively good preservation of glacial forms in contemporary relief were accepted, particularly beyond river valleys (e.g. Turkowska 2006).

Also, the amount of documentation of relief transformation in morphogenetic environments of moderate periods increased. The Eemian interglacial period remains quite difficult to evaluate, although valleys are becoming increasingly better recognised in this respect (Kołaczek et al. 2012 and other works). It is also worth noting that there was an advance in evaluation of the role of morphogenetic processes in the Holocene (Twardy 2008). The significant efficiency of these processes is related to results of direct and indirect human activity.

However, the author finds examples of such structures which cannot be associated with either glacial or periglacial environment. They are also not a record of moderate climate in the Eemian interglacial period or the Holocene. It is becoming increasingly clear also in connection with changes in definitions of the above environments. In particular, it concerns contemporary understanding of the following concepts: periglacial environment and paraglacial environment. It must be noted that irrespective of the progress in recognising the genesis of different structures, we are in the process of spontaneous and slow lexicalisation of scientific terms as well as intended evolution of many definitions of scientific terms, which results from the progress of research and the necessity of making them more precise.

\section{Periglacial environment}

Definitions of periglacial environment have changed quite radically. The term "periglacial" was introduced to literature by Łoziński (1909, 1912). His "periglacial facies" is generally a kind of eluvium - effect of frost action on sandstones in the Gorgany Mountains. The term "periglacial zone" was used with reference to the climatic and geomorphic conditions of areas peripheral to the Pleistocene ice sheets and glaciers.

The scale of periglacial phenomena as defined by Dylik (1964) is already much broader. He describes the periglacial environment as a set of frost and snow-ice morphological processes. He does not restrict their occurrence to the vicinity of ice-sheet. However, it is not widely accepted, since even in the 1970s, there were advocates of traditional definition of the periglacial zone, related with ice-sheet in terms of the area (Klimaszewski 1978).

On the other hand, Jahn's (1970) definition of the periglacial environment has clear climatic connotations - it is the scope of influence of dry and frosty climate, with its limits close to the isothermal line of average annual temperature of about $-1^{\circ} \mathrm{C}$.

According to Brown and Kupsch (1995), French (2007) and Slaymaker (2001) the present use of the term "periglacial" refers to frost processes in non-glacierized areas. Apart from processes related to permafrost, the role of seasonal, marine, lacustrine and fluvial ice as well as snow is taken into account. In this meaning the term is used in this paper.

\section{Glacial environment}

Direct impact of the ice-sheet seems to be explicitly defined. Some difficulties may appear when defining the extent of its impact in the case of indirect activity, e.g. meltwater operating in the foreland of a mountain glacier or ice-sheet. There is a zone around the ice-sheet and underneath it, which is penetrated by glacial processes in different ways. Distinguishing between glacigenic (subglacial) structures and those originated as a result of periglacial or paraglacial processes may be difficult there. However, there are models which explain it, for instance by Brodzikowski and Van Loon (1991).

Besides spatial distribution of individual environments, there is also a sequence of activity of individual processes in time. For instance, ice-moraine ridges are glacial forms at the time of their forming. However, in a situation of ongoing recession, when the ice-sheet front retreats from this accumulation of moraine sediments and dead-ice blocks, intense settlement processes begin to operate, redeposition of mineral material, numerous small slides and falls, polar solifluction, wash and other processes, which can be classified as belonging to the paraglacial environment, occur. 


\section{Paraglacial environment}

In Central Poland, as well as - and broader - in the landscape belt of the old glacial relief of the Polish Lowland, there are formations, sediments and their structures, which are difficult to classify as glacial or periglacial, and they are not typical of the impact of moderate climate. If we narrow periglacial processes down to a group of processes related to frost action (French 2007), there is a need to fill a "gap" encompassing a number of processes which are not strictly speaking glacial or periglacial, but rather "paraglacial". The term, though used only several times in Polish-language works, is more commonly used in English-language works (see Zwoliński 2007, Rachlewicz 2010, Strzelecki 2011), which refer to contemporary Arctic or Antarctic areas. However, it must be noted that no traces of fossil paraglacial features in lowland Poland have been described yet, all the more in the so-called old-glacial zone. Due to that, there is a gap which is already being filled in terminology used for describing contemporary processes of the cold zone. This also applies to Polish-language literature. The category includes paraglacial environment and related terms: "paraglacial processes" and "paraglacial relief".

It is worth reminding that the term "paraglacial" was first used in a Goddard's work (1965) on the geomorphology of Scotland. Formalised, it was used for the first time for defining nonglacial processes which occur as a result of glacial conditions and operate during a glaciation (Church and Ryder 1972). Analysing later publications, a conclusion may be drawn that the term is commonly understood as fast adaptation of glacial areas to nonglacial conditions (e.g.: Benn and Evans 1998, Mercier and Etienne 2008).

In 2002, Ballantyne proposed a new and broader definition of "paraglacial environment", recognising that they include: nonglacial geomorphological processes, sediment accumulation, landforms, landsystems and landscapes that are directly conditioned by glaciation and deglaciation. They are the subject of paraglacial geomor- phology. According to this author, the paraglacial system is characterised by instability. Duration of related processes - between $10^{1}$ and $10^{4}$ years. The area that is exposed as a result of ice-sheet retreat is very susceptible to rapid changes. Ballantyne (2002) distinguished 6 paraglacial landscape systems (sets): rocky slopes, slopes with moraine cover, glacier foreland, alluvial system, lacustrine system and coastal system.

Literature emphasises not only short-term operation of paraglacial processes, but also their particular sensitivity to the progress of warming. So state Knight and Harrison (2009), who also believe that knowledge of contemporary periglacial and paraglacial environments and those from the end of the last glaciation period and beginning of the Holocene is considerable, whereas we know very little about earlier glaciations. This results from poor preservation of structures due to pedogenic processes and evolution of flora, which restricts the application of the rule of uniformitarianism.

One may expect that landscape systems identified in Central Poland will be slightly different than those in contemporary areas released from ice-sheet under study, and the reconstruction will be more difficult.

\section{Examples of paraglacial structures and forms}

In the studies of characteristics of near-surface sediments that have been conducted so far in Central Poland, no traces of the paraglacial environment record were distinguished. A similar observation may also be referred to the entire Wartanian zone, which forms a latitudinal belt in Poland. Isolated cases of such record have been reported e.g. in the Sudetes Foreland within the extent of ice-sheet of the Odranian Glaciation (Saalian max.) in the form of paraglacial mass movements during adaptation of rock slopes of the Ślęża massif to the conditions of ice-sheet foreland (Traczyk and Kasprzak 2014).

Analysis of outcrops of Pleistocene formations, mostly Wartanian, allows for a number of such structures to be recognised as traces of paraglacial environment. This

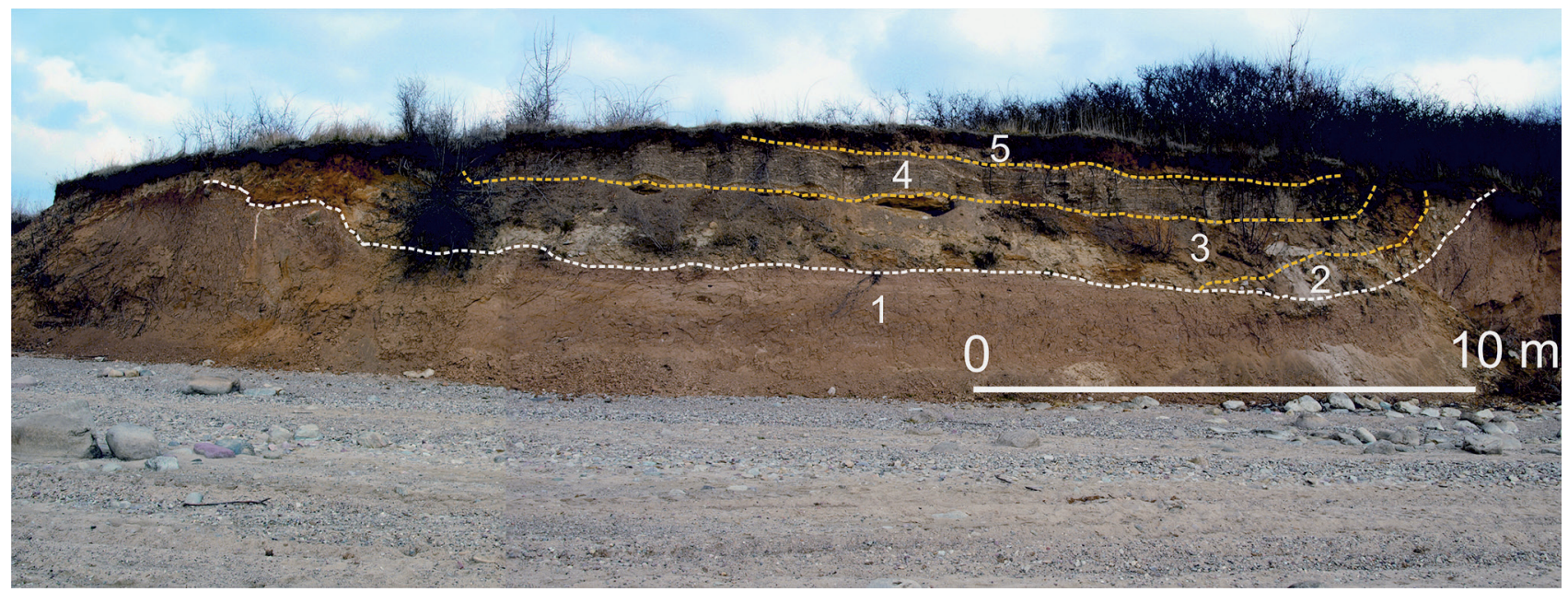

Fig. 3. Example of sedimentation in paraglacial conditions in a proglacial erosional channel, Siedlątków, Łask Upland Plain 1 - till, 2 - diamicton of debris flow, 3 - sandy sediments of a detrital fan, 4 - varved clay, 5 - sandy deluvia 
classification is based on definitions of paraglacial environment proposed by Slaymaker (2011).

Site 1. Siedlątków. The site is an example of filling a proglacial erosional channel as a result of several processes of the paraglacial environment. The structure of an erosional channel, 25-30 m wide and up to $2.5 \mathrm{~m}$ deep (Fig. 3 ) was found at the edge of a moraine plateau, which constitutes the edge of a contemporary anthropogenic cliff of the Jeziorsko Reservoir. Outline of the channel, marked with erosional stone pavement with boulders with radius of 50-60 cm, was formed as a result of cutting till during a high-energy flow of proglacial water. The channel was gradually filled with several sediment types:

- diamicton formation with a large number of boulders from debris-mud flow on the northern side of the slope, which was undercut by the channel (Fig. 3, 4, layer 2),

- sediments of a sandy detrital fan, 1-1.5 m thick (layer 3),

- varved sediments (>135 varves, layer 4),

- sandy sediments from surface wash (layer 5).

Site 2. Górki. The site features an example of gravitational deformations in the slope zone of a marginal landform with the structure of a glacifluvial-ablation fan as a result of settling on the melting dead-ice (Fig. 5). This structure proves that most deformations occurred after the glaciflu-

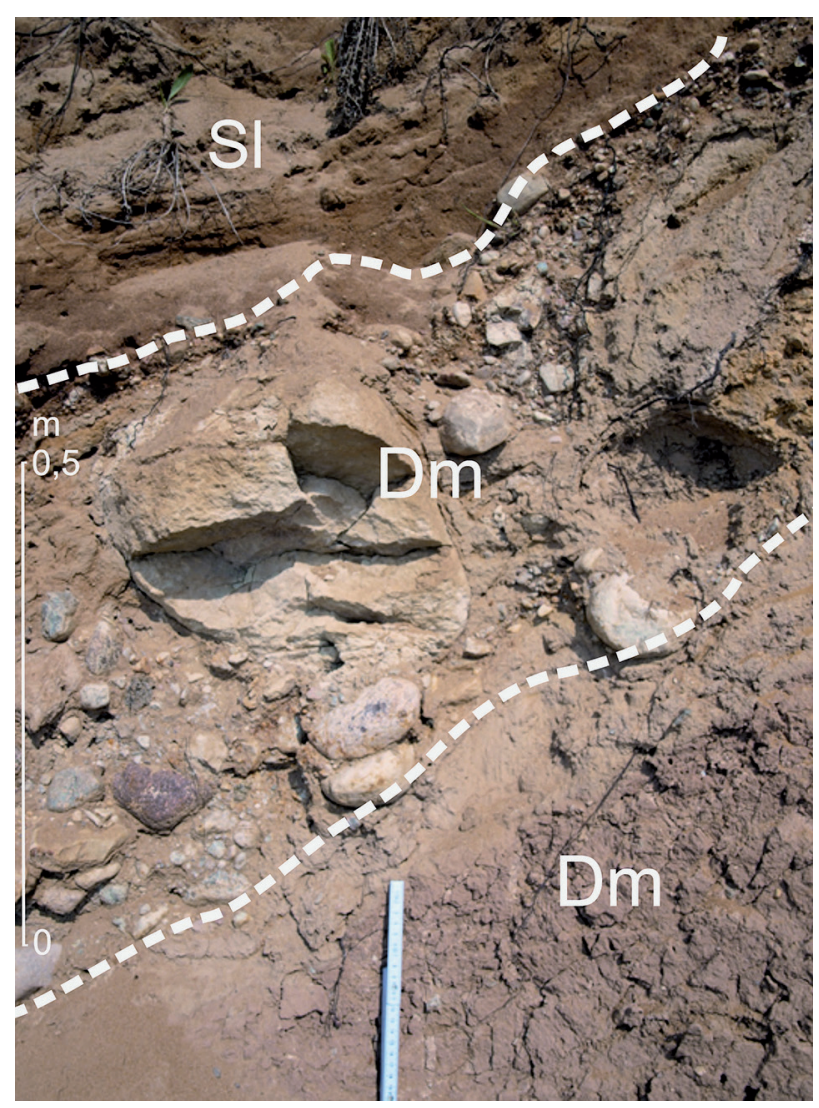

Fig. 4. Diamicton of debris flow sediments in marginal part of the channel structure, Siedlątków, Łask Upland Plain (see Fig. 3 , layer 2)

Lithofacial code: Dm - diamicton (till), DGm - diamicton of debris flow, $\mathrm{Sl}$ - low-angle sands

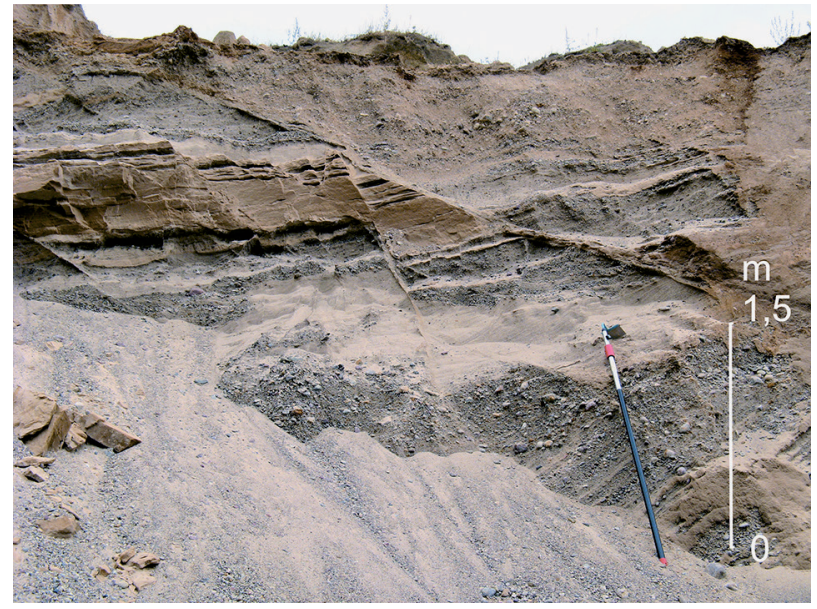

Fig. 5. Gravitational deformations in the structure of a glacifluvial-ablation ridge, Górki, Bełchatów Upland Plain

vial flow ceased. Due to this, genesis of these deformation structures should be interpreted as an effect of a paraglacial process. Many more such structures were documented in structures of kames and other glacifluvial landforms of the Łódź Region (Klajnert 1978, Rdzany 1997).

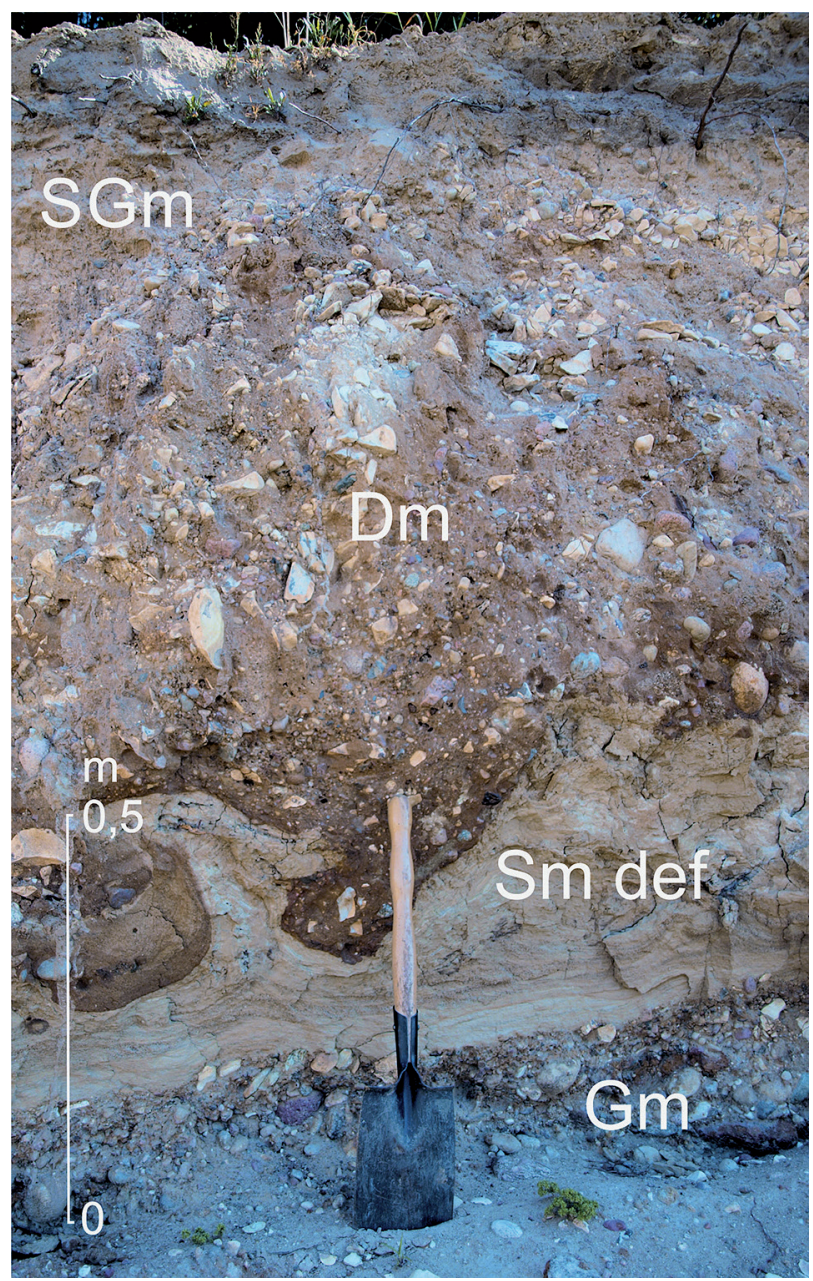

Fig. 6. Example of load casts formed in paraglacial conditions, Łaszczyn, Rawa Upland Plain

Lithofacial code: Gm - massive gravel, Sm def - massive sands with deformed structure, Dm - massive diamicton, $\mathrm{SGm}$ - massive gravely diamicton 
Site 3. Laszczyn. The outcrop shows examples of load deformations formed under paraglacial conditions in the slope part of an esker at the contact between diamicton of ablative origin and glacifluvial sands (Fig. 6). The deformations have similar characteristics to periglacial columnar involutions. A number of such deformations originated under conditions of high hydration of glacifluvial or ablative sediments without any relation to permafrost.

\section{Development of paraglacial environment in Central Poland - discussion}

The presented examples of record of paraglacial processes are not numerous, but this article aims mainly at their illustrational presentation, since so far, both here and in the entire Wartanian zone, they have not been distinguished at all (see Rdzany 2014a, b). Further research is necessary for closer acquaintance with them and more precise systematisation. At the current stage, there are no grounds for developing an advanced model, which would precisely show the diversity of this environment, but it is possible to establish general relations between the environments.

The observations so far allow for determining that the examples of paraglacial environment record are compatible with contemporary understanding of the term (e.g.: Ballantyne 2002, French 2007, Slaymaker 2011). They occupy small areas, between several square metres and several to about a dozen ares. They occur in isolation or form a mosaic with glacigenic, periglacial and other structures. Thus, the processes resulted at least in relief modifications which can be defined as local or mosaic; they were intense, diverse and characterised by rather limited range in the foreland of retreating ice-sheet. They included: limnic sedimentation in numerous, but small basins, mass movements, e.g. sediment slides on slopes of kames or other convex glacigenic forms, solifluction on slopes of kettle holes, settlement caused by melting of buried burried-ice and wash processes.

The described processes took place only after direct impact of ice-sheet or its meltwater had ceased. The processes occurred even before the interglacial warming of the Eemian. It has not been determined whether any of these processes continued during the Eemian interglacial period, although the determination may be possible in the course of further studies of Eemian fills found in kettle holes.

In order to better understand the importance of paraglacial processes in morphogenesis of the analysed area, some general regularities and relations between the environments in question must be analysed, not only in terms of the spatial layout but also the stratigraphic sequence. For Central Poland, it may be assumed that the original relief, when primary, main relief was formed, originated during the Warta Glaciation. A certain simplification in this statement must be accepted, as it is known that the relief was to a degree conditioned even by morphological elements of the Mesozoic bedrock. There are also cases of complex structure of relief forms, including palimpsest structure (Rdzany 1997, Rdzany and Jaksa 2002, Jaksa and Szmidt 2008, Szmidt 2012). Specificity of the glacigenic Wartanian relief must also be accounted for, which - particularly in Central Poland - is characterised by considerable vastness of glacifluvial forms (plateaux and several kilometre long kame ridges).

Periglacial transformations at the end of the Warta stage were present, but their record is very limited. If aggradation of permafrost occurred, as is possibly indicated by rare pseudomorphoses from syngenetic ice wedges, it was only of insular character (Rdzany 2009). There was also no clear development of eolian processes in the foreland of the Warta ice-sheet. However, such traces were found locally, near Bełchatów (Goździk 2007). Simplified, relief transformations in the Eemian interglacial period are linear and point-like: they are limited mostly to vertical erosion in river valleys, and in plateaux - to partial filling of kettle holes with lacustrine sediments and peats (Rdzany 1997, Petera 2002, Forysiak 2012, Majecka 2012). Record of the periglacial environment in the Vistulian is fairly widespread, but at the same time, spatially restricted to shallow, near-surface changes of structural and textural characteristics of sediments. In the case of relief, one must note a moderate evolution of valley bottoms, and formation of sets of eolian relief in valleys and on plateaux, where local diversification of relief occurred.

It is the author's conviction that periglacial changes to the Wartanian relief in the Vistulian were less intense than effects of paraglacial processes at the beginning of this evolution, and also less intense than the short-term relief changes under anthropopressure in the Holocene (see Twardy 2008). It must be noted that evaluation of the importance of the paraglacial environment is difficult, because in this environment, traces of many processes may be erased more quickly than in the periglacial environment. It must be stressed that in the periglacial environment, structures originate that penetrate the ground deeper, whereas some structures of the paraglacial environment are thin, as they were formed near ground surface. Simplified, it is a set of quite "ephemeral" traces, which makes reconstruction of such processes more difficult than in the case of periglacial processes, which penetrate the ground deep.

It does not mean that morphological effects will always be greater for a periglacial process than a paraglacial one. For instance, if an extensive clastic dike is formed as a result of water moving under high pressure in the sediment, in connection with the phenomenon of naled ice, changes in the relief may be slight. On the other hand, a paraglacial debris-mud flow could result in significant local changes in the morphology of this form. Thickness of sediments after such a process may be low.

It remains to be determined how distinguishing the paraglacial environment will influence the description of relief genesis in Central Poland. Referring to this issue is necessary, as even in contemporary literature we come 
across different terms coming from different stages of studies.

It is worth reminding that soon after traces of Pleistocene periglacial environment were discovered, the name "periglacial area" also functioned. Nowadays, such interpretation of relief hardly occurs anymore. Few cases of distinguishing "periglacial denudational plains" can be seen in older sheets of the Detailed Geological Map of Poland in the scale of 1:50,000.

The current state of knowledge of transformations of the original glacigenic relief offers no grounds for assuming an extreme view. It is not possible to prove the existence of e.g. extensive denudational plains of periglacial type both on plateau surfaces and in large proglacial valleys and river valleys. Nor is it possible to point to an area where all characteristics of the Wartanian young glacial landscape would be preserved. Thus, the term "young glacial relief" should be restricted - as it has been so far - to the extent of the Vistulian Glaciation (LGM); it is not applicable to relief of the Warta Glaciation zone.

Most commonly, Central Poland and the entire morphological zone of the Polish Lowland which was formed during the cold Wartanian stage are referred to as the belt of old glacial relief - it is the prevalent view and does not require changing in the light of the author's research. Post-Wartanian morphogenesis did not introduce significant changes in any of their first-order forms (larger moraine plateaux) in a degree that would allow to resign of the glacial element as the main discriminant of the described morphogenic zone.

It is also not possible to indicate an area where all characteristics of the Wartanian young glacial landscape would be preserved. Quantitative evaluation of the scale of processes responsible for evolution of the original relief is not yet possible. The descriptive model of the evolution may, however, be refined. Some revision is necessary, as literature includes many examples of too simplified views on this issue.

\section{Conclusions}

Distinguishing traces of the paraglacial environment is necessary to fill the gap that is present in the interpretation of genesis of the relief in Central Poland. This is a step towards making the model that explains the genesis and diversification of the relief and degree of its evolution more precise. In the light of the current knowledge, the view that the polygenic relief of the Warta belt in Central Poland is characterised by predominance of elements of old glacial relief should be maintained. Old glacial type of relief consists in co-occurrence within glacial forms of morphological and lithological elements which were formed in the paraglacial environment (Warta stage), periglacial environment (Warta stage, Vistulian) and fluvio-denudational environment from moderate periods (Eemian interglacial period, Holocene). Spatial and stratigraphic relations between them can be considerably diversified.
It must be noted that paraglacial forms have not been marked on geomorphological maps so far. It should be considered necessary that such distinctions be taken into account in designing a modern legend for geomorphological maps.

\section{Acknowledgment}

The research was conducted thanks to the resources of the Department of Physical Geography of the Łódź University.

I am indebted to the two anonimous referees for their useful comments and suggestions.

\section{References}

Ballantyne C.K., 2002, Paraglacial geomorphology. Quaternary Science Reviews 21: 1935-2017.

Benn D.I., Evans D.J.A., 1998. Glaciers and Glaciation. Arnold, London.

Brodzikowski K., Van Loon A.J., 1991. Glacigenic Sediments. Elsevier Science Publishers, Amsterdam.

Brown R.J.E., Kupsch W.O., 1995. Permafrost terminology. Biuletyn Peryglacjalny 32

Church M., Ryder J.M., 1972. Paraglacial sedimentation: consideration of fluvial processes conditioned by glaciation. Geological Society of America Bulletin 83: 3059-3072.

Dylik J., 1952. The concept of the periglacial cycle in Middle Poland. Bulletin de la Société des Sciences et des Lettres de Łódź 3 (5).

Dylik J., 1953. O peryglacjalnym charakterze rzeźby środkowej Polski. Acta Geographica Universitatis Lodziensis 4.

Dylik J., 1954. Zagadnienie powierzchni zrównań i prawa rozwoju rzeźby subarealnej. Czasopismo Geograficzne 25(3): 193-227.

Dylik J., 1964. Eléments essentiels de la notion de „periglaciaire“. Biuletyn Peryglacjalny 14: 111-132.

Eyles N., Eyles C.H. \& Miall A.D., 1983. Lithofacies types and vertical profile models; an alternative approach to the description and environmental interpretation of glacial diamict and diamictite sequences. Sedimentology 30: 393-410.

Forysiak J., 2012, Zapis zmian środowiska przyrodniczego późnego vistulianu i holocenu w osadach torfowisk regionu łódzkiego. Acta Geographica Lodziensia 99.

French H.M., 2007. The periglacial environment. John Wiley \& Sons, Ltd., Chichester.

Godard, A., 1965. Recherches en géomorphologie en Écosse du Nord-Ouest. Thèse d'État, Université de Paris Sorbonne, Les Belles Lettres.

Goździk J., 2007. The Vistulian Aeolian succession in central Poland. Sedimentary Geology 193: 211-220.

Jahn A., 1970. Zagadnienia strefy peryglacjalnej. PWN, Warszawa.

Jaksa Z., Rdzany Z., 2002. Sedymentologiczny zapis dynamiki deglacjacji Wysoczyzny Rawskiej na przykładzie Wału Rylska. Acta Universitatis Nicolai Copernici, Geografia XXXII - Nauki Matematyczno-Przyrodnicze 109: 169-181.

Jaksa A., Szmidt A., 2008. Wpływ tektoniki dysjunktywnej na rozmieszczenie kemów na obszarze województwa łódzkiego w świetle analizy kartograficznej. Landform Analysis 9: 146-150.

Klajnert Z., 1966. Geneza Wzgórz Domaniewickich i uwagi o sposobie zaniku lodowca środkowopolskiego. Acta Geographica Lodziensia 23.

Klajnert Z., 1978. Zanik lodowca warciańskiego na Wysoczyźnie Skierniewickiej i jej północnym przedpolu. Acta Geographica Lodziensia 38.

Klajnert Z., 1984. Analysis of kames for palaeogeographical reconstructions. Boreas, 13: 95-109.

Klatkowa H., 1972. Paleogeografia Wyżyny Łódzkiej i obszarów sąsiednich podczas zlodowacenia warciańskiego. Acta Geographica Lodziensia 28. 
Klimaszewski M., 1978. Geomorfologia, PWN, Warszawa.

Knight J., Harrison S. (eds), 2009. Periglacial and Paraglacial Processes and Environments. Geological Society, London, Special Publications 320.

Kondracki J., 2001. Geografia regionalna Polski. Wydawnictwo Naukowe PWN, Warszawa.

Krzemiński T., 1974. Geneza młodoplejstoceńskiej rzeźby glacjalnej w dorzeczu środkowej Warty. Acta Geographica Lodziensia 33.

Lencewicz S., 1927. Dyluwium i morfologia środkowego Powiśla. Prace Państwowego Instytutu Geologii, t. II.

Łoziński W., 1909. Über die mechanische Verwitterung der Sandsteine im gemässigten Klima. Bulletin International de l'Academie des Sciences de Cracovie 1.

Łoziński W., 1912. Die periglaziale Fazies der mechanischen Verwitterung. Comptes Rendus, XI Congrès Internationale Géologie, Stockholm 1910: 1039-1053.

Miall A.D., 1977. A review of the braided river depositional environment. Earth-Science Reviews 13: 1-62.

Miall A.D., 1978. Lithofacies types and vertical models in braided river deposits: a summary. In: A.D. Miall (ed.), Fluvial Sedimentology. Canadian Society of Petroleum Geologists, Memoir 5: 597-604.

Kołaczek P., Karpińska-Kołaczek M., Petera-Zganiacz J., 2012. Vegetation patterns under climate changes in the Eemian and Early Weichselian in central Europe inferred from a palynological sequence from Ustków (Central Poland). Quaternary International 268: 9-20.

Majecka A., 2012. Postwarciańskie przekształcenia rzeźby obszarów wododziałowych na Wysoczyźnie Łódzkiej (na przykładzie międzyrzecza Mrogi i Mrożycy). MS PhD, Katedra Geomorfologii Uniwersytetu Łódzkiego.

Mercier D., Etienne S., 2008, Preface. Paraglacial geomorphology: Processes and paraglacial context. Geomorphology 95: 1-2.

Petera J., 2002. Vistuliańskie osady dolinne w basenie uniejowskim i ich wymowa paleogeograficzna. Acta Geographica Lodziensia 83.

Rachlewicz G., 2007. Petuniabukta - from glacial to paraglacial processes in Ebbadalen. Landform Analysis 5: 189-191.

Rachlewicz G. 2010. Paraglacial modifications of glacial sediments over millennial to decadal time-scales in the High-Arctic (Billefjorden, central Spitsbergen, Svalbard). Quaestiones Geographicae 29(3): 59-67.

Rdzany Z., 1997. Kształtowanie rzeźby terenu między górną Rawką a Pilicą w czasie zaniku lądolodu warciańskiego. Acta Geographica Lodziensia 73.

Rdzany Z., 2009. Rekonstrukcja przebiegu zlodowacenia warty w regionie łódzkim. Wydawnictwo Uniwersytetu Łódzkiego, Łódź.
Rdzany Z., 2014a. Zanik młodoglacjalnej rzeźby warciańskiej - przekształcenia peryglacjalne czy paraglacjalne?. Streszczenie referatu, X Zjazd SGP „Krajobrazy młodoglacjalne, ich morfogeneza, teraźniejszość, przyszłość". Toruń.

Rdzany Z., 2014b. Stages of evolution of the glacial landsystem in Central Poland after Warta Glaciation (Late Saalian). Geomorphology and Environmental Challenges. Geomorfológia a environmentálne výzvy. 8 vedecká konferencja Asociácie slovenských geomorfólov pri SAV. Snina 6-8.10.2014. Book of Abstracts, Bratislava.

Slaymaker O., 2011. Criteria to distinguish between periglacial, proglacial and paraglacial environments. Quaestiones Geographicae 30(1): 85-94.

Strzelecki M., 2011. Paraglacial processes operating on High Arctic coastal margins - recent advances from Svalbard. Geophysical Research Abstracts, 13, EGU2011-87-1.

Szmidt A., 2012. Wpływ podłoża na rzeźbę i osady czwartorzędu na obszarze województwa łódzkiego w świetle wybranych metod GIS. MS $\mathrm{PhD}$, Katedra Geografii Fizycznej Uniwersytetu Łódzkiego.

Traczyk A., Kasprzak M., 2014. Plejstoceńska rzeźba stoków masywu Ślęży (Przedgórze Sudeckie) - reinterpretacja na podstawie danych LiDAR oraz pomiarów elektrooporowych (ERT). Streszczenia, X Zjazd Geomorfologów Polskich, Toruń 16-19 września 2014 „Krajobrazy młodoglacjalne, ich morfogeneza, teraźniejszość, przyszłość”, Toruń, 111-112.

Turkowska K., 1988. Rozwój dolin rzecznych na Wyżynie Łódzkiej w późnym czwartorzędzie. Acta Geographica Lodziensia 57.

Turkowska K., 1996. Przykłady dolin poligenicznych w regionie łódzkim. Acta Geographica Lodziensia 71: 243-258.

Turkowska K., 2006. Geomorfologia regionu łódzkiego. Wydawnictwo Uniwersytetu Łódzkiego, Łódź.

Twardy J., 2008. Transformacja rzeźby centralnej części Polski Środkowej w warunkach antropopresji. Wydawnictwo Uniwersytetu Łódzkiego, Łódź.

Strzelecki M.C., 2011. Cold shores in warming times - current state and future challenges in Arctic coastal evolution studies. Quaestiones Geographicae 30(3): 103-115.

Zieliński T., Pisarska-Jamroży M., 2012. Jakie cechy litologiczne warto kodować, a jakie nie? Przegląd Geologiczny 60: 387-397.

Zwoliński, Z., 2007. Mobilność materii mineralnej na obszarach paraglacjalnych, Wyspa Króla Jerzego, Antarktyka Zachodnia. Wydawnictwo Naukowe Uniwersytetu Adama Mickiewicza, Seria Geografia, 74, Poznań. 